\title{
Propionibacterium freudenreichii Surface Protein SIpB Is Involved in Adhesion to Intestinal HT-29 Cells
}

\section{Fillipe L. R. do Carmo 1,2, Houem Rabah',3, Song Huang 2,4, Floriane Gaucher2, Martine Deplanche ${ }^{2}$, Stéphanie Dutertre ${ }^{5}$, Julien Jardin'2, Yves Le Loir ${ }^{2}$, Vasco Azevedo ${ }^{1 \dagger}$ and Gwénaël Jan ${ }^{2 *}$}

\begin{abstract}
${ }^{1}$ Federal University of Minas Gerais - Instituto de Ciências Biológicas, Belo Horizonte, Brazil, ${ }^{2}$ Science et Technologie du Lait et de l'Oeuf, Institut National de la Recherche Agronomique, Agrocampus Ouest, Rennes, France, ${ }^{3}$ Pôle Agronomique Ouest, Rennes, France, ${ }^{4}$ Suzhou Key Laboratory of Green Chemical Engineering, School of Chemical and Environmental Engineering, College of Chemistry, Chemical Engineering and Material Science, Soochow University, Suzhou, China,

${ }^{5}$ Microscopy Rennes Imaging Center, Biosit - UMS CNRS 3480/US, INSERM 018, University of Rennes 1, Rennes, France
\end{abstract}

Propionibacterium freudenreichii is a beneficial bacterium traditionally used as a cheese ripening starter and more recently for its probiotic abilities based on the release of beneficial metabolites. In addition to these metabolites (short-chain fatty acids, vitamins, and bifidogenic factor), $P$. freudenreichii revealed an immunomodulatory effect confirmed in vivo by the ability to protect mice from induced acute colitis. This effect is, however, highly strain-dependent. Local action of metabolites and of immunomodulatory molecules is favored by the ability of probiotics to adhere to the host cells. This property depends on key surface compounds, still poorly characterized in propionibacteria. In the present study, we showed different adhesion rates to cultured human intestinal cells, among strains of $P$. freudenreichii. The most adhesive one was P. freudenreichii CIRM-BIA 129, which is known to expose surface-layer proteins. We evidenced here the involvement of these proteins in adhesion to cultured human colon cells. We then aimed at deciphering the mechanisms involved in adhesion. Adhesion was inhibited by antibodies raised against SlpB, one of the surface-layer proteins in P. freudenreichii CIRM-BIA 129. Inactivation of the corresponding gene suppressed adhesion, further evidencing the key role of $s / p B$ product in cell adhesion. This work confirms the various functions fulfilled by surface-layer proteins, including probiotic/host interactions. It opens new perspectives for the understanding of probiotic determinants in propionibacteria, and for the selection of the most efficient strains within the $P$. freudenreichii species.

Keywords: adhesion, immunomodulation, surface proteins, probiotic, SIpB

\section{INTRODUCTION}

Propionibacterium freudenreichii is a GRAS (Generally Recognized $\underline{\text { As }} \underline{\mathrm{S}} \mathrm{afe}$ ) actinobacterium consumed in high amounts in fermented dairy products. It is a beneficial bacterium used in the food industry for the production of vitamins, for cheese ripening, and for its probiotic properties (Cousin et al., 2010). Probiotics are defined as "living microorganisms which when administered in adequate amounts confer a health benefit on the host" (Food and Agriculture Organization of the United Nations and World Health Organization, 2002). P. freudenreichii indeed revealed probiotic 
traits including modulation of intestinal inflammation (Mitsuyama et al., 2007; Foligné et al., 2010, 2013), as well as properties linked to the production of beneficial metabolites such as short-chain fatty acids (Jan et al., 2002; Lan et al., 2007; Cousin et al., 2012b), vitamins and the bifidogenic compound 1,4-dihydroxy-2-naphthoic acid (DHNA) (Bouglé et al., 1999; Kaneko, 1999; Hojo et al., 2002; Ouwehand et al., 2002; Seki et al., 2004; Mitsuyama et al., 2007).

Microorganisms that live in or transit through the digestive tract of humans may establish a symbiotic relationship with the host, thus promoting intestinal homeostasis (de Souza and Fiocchi, 2016). Consumption of $P$. freudenreichii selected strains can enhance human complex intestinal microbiota through the increase of other beneficial bacteria populations, such as bifidobacteria (Bouglé et al., 1999; Kaneko, 1999; Hojo et al., 2002; Ouwehand et al., 2002; Seki et al., 2004; Mitsuyama et al., 2007). In contrast, out of normal physiological conditions, the digestive microbiota may be involved in a variety of immune and inflammatory disorders (Vitetta et al., 2014). One example is inflammatory bowel diseases (IBD), chronic inflammatory disorders that severely affect the digestive tract and may lead, in the long term, to the irreversible deterioration of their structure and function (Belkaid and Hand, 2014; Vitetta et al., 2015). Cheese containing P. freudenreichii, in conjunction with Lactobacillus delbrueckii (Plé et al., 2016) or as a single strain (Plé et al., 2015), was recently shown to exert immunomodulatory effects, to protect mice against TNBSinduced colitis, to alleviate the severity of symptoms and to modulate local and systemic inflammation markers. Such cheese is currently tested in a pilot clinical trial (ClinicalTrials.gov, 2017). Interestingly, removal of propionibacteria surfacelayer (S-layer) proteins, which are non-covalently anchored to the cell surface via an S-layer homology (SLH) domain, suppressed the induction of anti-inflammatory cytokines (Foligné et al., 2010). By contrast, some P. freudenreichii strains that possess an extracellular polysaccharide capsule fail to immunomodulate, while mutagenetic suppression of this capsule confers immunomodulatory activity (Deutsch et al., 2012).

Surface proteins of $P$. freudenreichii ITG P20 [Centre International de Ressources Microbiennes-Bactéries d'Intérêt Alimentaire (CIRM-BIA) 129], which is used as a cheese ripening starter (Richoux et al., 1998; Thierry et al., 2004), were investigated by a combination of proteomic methods previously developed for bacteria and eukaryotic cells (Lortal et al., 1993; Mayrhofer et al., 2006; Rodríguez-Ortega et al., 2006; Berlec et al., 2011; Bøhle et al., 2011; Bensi et al., 2012; Ythier et al., 2012; Michaux et al., 2013). This investigation demonstrated the involvement of certain S-layer proteins in immunomodulation (Bryson et al., 2006; Le Maréchal et al., 2015). Surface proteins, susceptible to enzymatic shaving and to guanidine extraction, were shown to be involved in the ability of $P$. freudenreichii to modulate the release of cytokines by human immune cells (Le Maréchal et al., 2015). However, the respective role of the different bacterial S-layer proteins was not fully elucidate. Immunomodulation is favored by the ability of specific strains to adhere to the host cells and mucus (Tuomola et al., 1999; Ouwehand et al., 2000; Huang and Adams, 2003; Thiel et al., 2004;
Le Maréchal et al., 2015). Indeed, the local action of metabolites and of immunomodulatory molecules is favored by the ability of probiotics to adhere to the host cells. Dairy propionibacteria were shown to adhere to mice intestinal epithelial cells both ex vivo and in vivo (Zarate, 2012) as well as to cultured human intestinal cell lines in vitro (Huang and Adams, 2003; Moussavi and Adams, 2010). However, the precise mechanisms are poorly characterized in $P$. freudenreichii. Adhesion moreover constitutes a key criterion in strain selection and is described as the initial step for colonization of the host (Havenaar et al., 1992, havenar; Riedel et al., 2006; Preising et al., 2010), depending on crucial surface compounds, including surface proteins (Lebeer et al., 2010).

The identification of adhesion mechanisms and molecules is a fundamental step in the elucidation of the bacterium/host cross-talk (van de Guchte et al., 2012). This was lacking in probiotic dairy propionibacteria. The aim of our study was thus to identify $P$. freudenreichii protein(s) involved in adhesion to human intestinal epithelial cells.

\section{MATERIALS AND METHODS}

\section{Bacterial Strains and Culture Conditions}

The $P$. freudenreichii wild-type (WT) strains, genetically modified strain and plasmids used in this study are listed in Table 1. All strains in this study were obtained from the collection of the CIRM-BIA (STLO, INRA Rennes, France). All P. freuderenichii WT strains were grown at $30^{\circ} \mathrm{C}$ in YEL broth (Malik et al., 1968) without agitation or in cow's milk ultrafiltrate supplemented with $50 \mathrm{mM}$ of sodium L-lactate (galaflowSL60, Société Arnaud, Paris, France) and $5 \mathrm{~g} / \mathrm{L}$ of casein hydrolysate (Organotechnie, La Courneuve, France), sterilized by $0.2 \mu \mathrm{m}$ filtration (Nalgene, Roskilde, Denmark) as described previously (Cousin et al., 2012a). For genetically modified strains, YEL and Milk Ultrafiltrate culture media were supplemented with chloramphenicol $\left(10 \mu \mathrm{g} \mathrm{ml}^{-1}\right)$. The growth of $P$. freudenreichii strains was monitored spectrophotometrically by measuring the optical density at $650 \mathrm{~nm}$ (OD650), as well as by counting colony-forming units (CFUs) in YEL medium (Malik et al., 1968) containing $1.5 \%$ agar. $P$. freudenreichii strains was harvested in a stationary phase $\left(76 \mathrm{~h}, 10^{9} \mathrm{CFU} / \mathrm{mL}\right.$, determined by plate counts) by centrifugation $\left(6,000 \times \mathrm{g}, 10 \mathrm{~min}, 4^{\circ} \mathrm{C}\right)$. Escherichia coli strain $\mathrm{DH} 5 \alpha$ was grown in Luria-Bertani medium at $37^{\circ} \mathrm{C}$, and cells carrying DNA plasmid were selected by addition of ampicillin $\left(100 \mu \mathrm{g} \mathrm{ml}^{-1}\right)$.

\section{Enzymatic Shaving of Surface Proteins}

One hundred microliter of propionibacteria stationary phase culture (see above) were harvested by centrifugation $(6,000 \times g$, $10 \mathrm{~min}, 4^{\circ} \mathrm{C}$ ) and washed in an equal volume of PBS [pH 8.5] containing $5 \mathrm{mM}$ DTT before resuspension in $1 / 10$ volume of the same buffer. Sequencing grade modified trypsin (V5111, Promega, Madison, WI, United States) was dissolved in the same buffer (qsp $0.2 \mathrm{~g} / \mathrm{L}$ ) and added to the bacterial suspension. "Shaving" was performed for $1 \mathrm{~h}$ at $37^{\circ} \mathrm{C}$ in a $0.5 \mathrm{~mL}$ reaction volume containing $5 \times 10^{9}$ bacteria and $4 \mu \mathrm{g}$ of trypsin, 
TABLE 1 | Propionibacterium freudenreichii wild-type strains, their genetically modified derivatives and plasmids used in the study.

\begin{tabular}{|c|c|c|}
\hline $\begin{array}{l}\text { Strains and } \\
\text { plasmids }\end{array}$ & Relevant genotype and phenotype & $\begin{array}{l}\text { Source or } \\
\text { reference }\end{array}$ \\
\hline \multicolumn{3}{|c|}{ Strains $P$ freudenreichii ${ }^{\mathrm{a}}$} \\
\hline CB 118 & $\begin{array}{l}\text { Wild-type; SIpA, SIpB, SIpE, and InIA } \\
\text { proteins detected in guanidine extract }\end{array}$ & CIRM-BIA \\
\hline CB 121 & $\begin{array}{l}\text { Wild-type; InIA and LspA proteins detected } \\
\text { in guanidine extract }\end{array}$ & CIRM-BIA \\
\hline CB 129 & $\begin{array}{l}\text { Wild-type; SIpA, SIpB, SIpE, InIA, and LspA } \\
\text { proteins detected in guanidine extract }\end{array}$ & CIRM-BIA \\
\hline CB 134 & $\begin{array}{l}\text { Wild-type; SIpA, SIpE, InIA, and LspA } \\
\text { proteins detected in guanidine extract }\end{array}$ & CIRM-BIA \\
\hline CB 136 & $\begin{array}{l}\text { Wild-type; SIpA, SIpB, InIA, and LspA } \\
\text { proteins detected in guanidine extract }\end{array}$ & CIRM-BIA \\
\hline CB 508 & $\begin{array}{l}\text { Wild-type; SIpA, SIpB, SIpE, InIA, and LspA } \\
\text { proteins detected in guanidine extract }\end{array}$ & CIRM-BIA \\
\hline CB 527 & $\begin{array}{l}\text { Wild-type; Absence of surface layer } \\
\text { proteins in guanidine extract }\end{array}$ & CIRM-BIA \\
\hline CB $129 \Delta s / p B$ & $\begin{array}{l}\mathrm{Cm}^{r} \text {; CIRM-BIA } 129 \text { with chromosomal } \\
\text { insertion of pUC: } \Delta s / p B: C m R \text { in the s/pB } \\
\text { sequence; SIpB protein absent in guanidine } \\
\text { extract }\end{array}$ & This Study \\
\hline \multicolumn{3}{|l|}{ Plasmids } \\
\hline pUC:slpB & $\begin{array}{l}\text { pUC18; Amp; harboring s/pB partial gene } \\
\text { sequence for inactivation }\end{array}$ & This Study \\
\hline pUC: $\Delta$ slpB:CmR & $\begin{array}{l}\text { pUC18 carrying a chloramphenicol } \\
\text { resistance gene and harboring } \operatorname{s} p B \text { partial } \\
\text { gene sequence }\end{array}$ & This Study \\
\hline \multicolumn{3}{|c|}{ 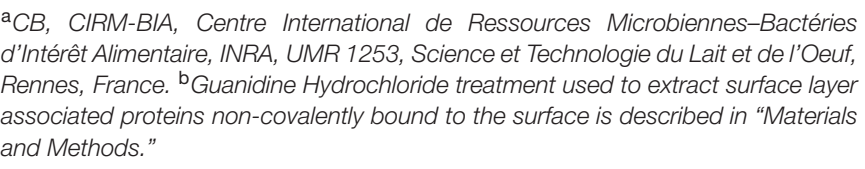 } \\
\hline
\end{tabular}

with gentle agitation $(180 \mathrm{rpm})$. Bacteria were removed by centrifugation $\left(8,000 \times g, 10 \mathrm{~min}, 20^{\circ} \mathrm{C}\right)$ and subjected to three washes in PBS prior to adhesion assay.

\section{Cell Line and Culture Conditions}

The human colon adenocarcinoma cell line HT-29 was obtained from ATCC (American Type Culture Collection, Rockville, MD, United States). These cells was cultured under conditions of $37^{\circ} \mathrm{C}$, $5 \% \mathrm{CO}_{2}$, and $90 \%$ relative humidity in DMEM High Glucose with L-Glutamine with Sodium Pyruvate (PAN, Dominique Dutscher, Brumath, France) supplemented with 10\% heat-inactivated fetal calf serum (FCS) (PAN, Dominique Dutscher, Brumath, France) and antibiotics or not (for adhesion assays).

\section{Electroporation and Inactivation of the slpB Gene in $P$. freudenrenichii CIRM-BIA 129 by Suicide Vector}

Inactivation of $P$. freudenreichii gene was adapted from Deutsch et al. (2012) with some modifications. For insertional inactivation of a $\operatorname{slp} B$ gene, a 520-bp DNA fragment homologous to nucleotides $30-550$ of the $5^{\prime}$ region of the slpB coding region in P. freudenreichii CIRM-BIA 129 genome was synthesized by Genscript Inc. ${ }^{1}$ with restriction sites $X b a I-s l p B-5^{\prime}$ and $B a m H I-s l p B-3^{\prime}$ resulting in pUC: $\Delta s l p B$ plasmid. The pUC: $\Delta s l p B$ plasmidic DNA was digested with XbaI and BamHI, purified, and cloned in plasmid pUC:CmR digested by the same enzymes, which resulted in the suicide vector pUC: $\Delta \operatorname{sl} B: \mathrm{CmR}$, which was confirmed by sequencing. See Supplementary Figure S2.

Electrocompetent $P$. freudenreichii CIRM-BIA 129 cells was prepared as previously described (Deutsch et al., 2012) with slight modifications. They were cultured in YEL medium supplemented with $0.5 \mathrm{M}$ sucrose and $2 \%$ glycine until the early exponential growth phase $(\mathrm{OD}=0.1)$, harvested $\left(6,000 \times g, 10 \mathrm{~min}, 4^{\circ} \mathrm{C}\right)$. The pellet was washed extensively in ice-cold $0.5 \mathrm{M}$ sucrose and resuspended in electroporation buffer containing $0.5 \mathrm{M}$ sucrose with $10 \%$ glycerol and $1 \mathrm{mM}$ potassium acetate $(\mathrm{pH} 5.5)$. For electroporation, a $100-\mu \mathrm{l}$ aliquot of the electrocompetent cells was mixed with $3 \mu \mathrm{g}$ of pUC: $\Delta \operatorname{sip} B: C m \mathrm{R}$ plasmid DNA in a cooled electroporation cuvette. The electroporation of P. freudenreichii CIRM-BIA 129 was performed with a Gene Pulser Xcell ${ }^{\mathrm{TM}}$ (Bio-Rad Laboratories, Richmond, CA, United States) at $20 \mathrm{kV} / \mathrm{cm}, 200-\Omega$ resistance, and $25-\mu \mathrm{F}$ capacitance. Immediately after the pulse, $900 \mu \mathrm{L}$ of YEL containing $0.5 \mathrm{M}$ sucrose, $20 \mathrm{mM} \mathrm{MgCl}_{2}$, and $2 \mathrm{mM} \mathrm{CaCl} 2$ were added before incubation, $24 \mathrm{H}$ at $30^{\circ} \mathrm{C}$ under microaerophilic conditions. Cells were plated, and incubated 7 days at $30^{\circ} \mathrm{C}$ under anaerobic conditions, on YEL medium containing 1.5\% agar (YELA) supplemented with $10 \mu \mathrm{g} \cdot \mathrm{ml}^{-1}$ of chloramphenicol in order to select $P$. freudenreichii mutants harboring inserted pUC: $\Delta s l p B: C m \mathrm{R}$. The P. freudenreichii CIRM-BIA $129 \Delta s l p B$ (CB129 $\Delta s l p B$ ) mutant strain was further checked by proteomics for the absence of intact SlpB surface proteins as indicated in the "Results" section. Moreover, the stability of the insertion was checked after three independent cultures in YEL and Milk Ultrafiltrate media without chloramphenicol.

\section{In Vitro Adhesion Assays}

Adhesion of $P$. freudenreichii (WT and mutant) to the human colon adenocarcinoma cell line HT-29 was examined by adding $10^{8}$ live propionibacteria (washed twice in PBS, numerated by CFU conting, ratio 100 bacteria:1 HT-29 cell, MOI 100) to $10^{6}$ cells in DMEM culture medium without antibiotics. Adhesion assay was conducted by incubation of bacteria/cell at $37^{\circ} \mathrm{C}$ for 60 min under conditions, $5 \% \mathrm{CO}_{2}$ and $90 \%$ relative humidity. Cells were washed twice with prewarmed PBS pH 7.4, and the subsequently supernatant was removed, and $400 \mu \mathrm{L}$ of trypsin-EDTA (Invitrogen) was added to each well, before incubation for $5 \mathrm{~min}$ at $37^{\circ} \mathrm{C}$ and to trypsin inactivation by adding $800 \mu \mathrm{L}$ of DMEM culture medium without antibiotics. Cells were harvested $(3,000 \times g, 3 \mathrm{~min})$ and lysed in $0.1 \%$ Triton $\mathrm{X}-100$ before serial dilutions and plating on YELA. Finally, plates were incubated at $30^{\circ} \mathrm{C}$ for 5 days under anaerobic conditions. A rate of adhesion was calculated as follows: (bacterial count after adhesion experiment/bacterial population added on to HT29 cells). The CIRM-BIA 129 WT strain was then used as a reference in this work, with a \% adhesion of 100, and used

\footnotetext{
${ }^{1}$ www.genscript.com
} 
to normalize all other adhesion rates as a percentage of CIRMBIA 129 WT adhesion. Each adhesion assay was conducted in technical and biological triplicates. To test involvement of surface proteins in adhesion, propionibacteria were subjected (or not) to enzymatic shaving (see section "Enzymatic Shaving of Surface Proteins") before adhesion assay. To confirm this hypothesis, propionibacteria were incubated $60 \mathrm{~min}$ at $37^{\circ} \mathrm{C}$ with $50 \mu \mathrm{g}$ of $P$. freudenreichii CIRM-BIA 129 guanidineextracted S-layer associated proteins, in solution in PBS, under agitation, before adhesion. This amount ( $50 \mu \mathrm{g})$ was determined after preliminary experiments to determine amounts efficient in restoring adhesion. For specific inhibition of adhesion by antibodies directed against SlpB, propionibacteria were incubated in PBS pH 7.4 with immunoglobulins purified from rabbit antiSlpB serum (AGRO-BIO, France) in 1:10.000 dilution, under agitation, $60 \mathrm{~min}$ at $37^{\circ} \mathrm{C}$. Propionibacteria were washed twice with PBS pH 7.4 before adhesion assay.

The adhesion ratio of CB 129 strain alone was used as a reference to calculate the adhesion rates of different strains and treatments.

Internalization of bacteria was determined as previously described (Bouchard et al., 2013) 2-h post contact following an additional 2-h incubation step with DMEM supplemented with gentamicin $(100 \mu \mathrm{g} / \mathrm{ml})$ to kill extracellular bacteria. Subsequently, HT-29 cells monolayers were washed three times with PBS, treated with trypsin, centrifuged for 5 min at $800 \times g$, and lysed in $0.01 \%$ Triton to allow the numeration of internalized propionibacteria population only.

\section{Bacterial Cell Adhesion Observation by Microscopy}

Observation of $P$. freudenreichii adhesion to cultured human colon epithelial cells was as described previously for lactobacilli (Tiptiri-Kourpeti et al., 2016), with modifications for propionibacteria. Briefly, propionibacteria, cultured as described above, were washed and resuspended in PBS, prior to the addition of $20 \mu \mathrm{M}$ CFSE (carboxyfluorescein succinimidyl ester, cell trace proliferation kit for flow cytometry ref C34554 Thermo Fisher Scientific, Waltman, MA, United States), freshly prepared as a $1,000 \times$ solution in DMSO and kept in the dark. Incorporation of CFSE was allowed for $30 \mathrm{~min}$ at $30^{\circ} \mathrm{C}$ in the dark, prior to washing and resuspension of propionibacteria in YEL medium, $30^{\circ} \mathrm{C}$. Hydrolysis of CFSE by intracellular esterase activity was allowed $30 \mathrm{~min}$ at $30^{\circ} \mathrm{C}$ in the dark to generate intracellular fluorescence. Fluorescence was checked on an epifluorescence microscope (BX-51, Olympus, equipped with a U-MWB2 fluorescence filter cube). HT-29 cells were cultured in Lab-Tek chamber slide (Thermo Fisher Scientific) and labeled bacteria were added to a $1 / 100$ ratio $\left(1 \times 10^{6}\right.$ cells, $1 \times 10^{8}$ bacteria, in $1 \mathrm{~mL}$ of DMEM) before incubation, $1 \mathrm{~h}$, $37^{\circ} \mathrm{C}$. After two washes with PBS, the plasma membrane of cells was then labeled with the exogenous head-labeled phospholipid fluorescent probe $\mathrm{N}$-(Lissamine rhodamine B sulfonyl) dioleoyl phosphatidylethanolamine (Rh-DOPE, Avanti Polar Lipids Inc., Birmingham, England) used at a concentration of $1 \mu \mathrm{g} / \mathrm{mL}$ in DMEM, for $10 \mathrm{~min}$. Cell layer was then washed twice with PBS and slides mounted in DAPI (4,6-diamidino-2-phenylindole)containing mounting medium (Vectashield mounting medium for fluorescence Vector ref $H-1200$ ). Cells were observed using a confocal Leica SP8 and a 63/1.4 oilHC PL APO CS objective. Images were acquired using LAS-AF (Leica, Wetzlar, Germany) software.

For scanning electron microscopy, HT-29 cells were cultured in Corning ${ }^{\circledR}$ Transwell ${ }^{\circledR}$ polycarbonate membrane cell culture inserts on polycarbonate $0.4 \mu \mathrm{m}$ pore size filtration membrane. Adhesion was conducted as described above. Membranes were then removed, washed in PBS, fixed $48 \mathrm{~h}$ by $2 \%$ (wt/vol) glutaraldehyde in $0.1 \mathrm{M}$ sodium cacodylate buffer [pH 6.8] and rinsed in the same buffer. Samples were dehydrated with ethanol $(10,25,50,75,95$, and finally $100 \%)$, critical-point dried by the $\mathrm{CO}_{2}$ method and coated with gold. Cells were examined and photographed with a Philips XL 20 scanning electron microscope operating at $10 \mathrm{kV}$.

\section{Bacterial Cell Adhesion Determination by Cytometric Analysis}

Determination of $P$. freudenreichii adhesion to cultured human colon epithelial cells was performed as described previously for lactobacilli (Tiptiri-Kourpeti et al., 2016). Cells were cultured in DMEM as described above to confluence. CFSE-labeled bacteria were added as described above before a $1-\mathrm{h}$ incubation at $37^{\circ} \mathrm{C}$. Cells were trypsinized and analyzed by fluorescence cytometry using an excitation wavelength of 488 and emission at $585 \mathrm{~nm}$ (Accuri C6 Becton Dickinson, Le Pont-de-Claix, France). Data were collected from 50,000 cells and analysis was performed with CFlow software.

\section{Guanidine Extraction of Surface Layer Associated Proteins Non-covalently Bound to the Cell Wall}

Propionibacteria cultures in stationary phase $(76-\mathrm{h})$ were collected by centrifugation $\left(8,000 \times g, 10 \mathrm{~min}, 4^{\circ} \mathrm{C}\right)$ for extraction of S-layer proteins by Guanidine Hydrochloride (GuaHCl) (Le Maréchal et al., 2015). The bacterial pellet was washed two times with an equal volume of PBS buffer $\mathrm{pH}$ 7.4. This pellet was resuspended in $5 \mathrm{M} \mathrm{GuaHCl}$ to a final $\mathrm{OD}_{650}$ of 20 then incubated $15 \mathrm{~min}$ at $50^{\circ} \mathrm{C}$, and subsequently, the suspension was centrifuged $\left(21.000 \times \mathrm{g}, 20 \mathrm{~min}, 30^{\circ} \mathrm{C}\right)$. The cells were eliminated, and the supernatant was dialyzed extensively against PBS buffer pH 7.4 (for adhesion assays) or 0.1\% SDS (for SDSPAGE analysis) for $24 \mathrm{~h}$ at $4^{\circ} \mathrm{C}$ using Slide-A-Lyer ${ }^{\circledR}$ Dialysis Cassette (ThermoScientific, Rockford, IL, United States). This procedure was applied in three independent cultures.

\section{One-Dimensional SDS-Polyacrylamide Gel Electrophoresis (1-DE) and Western Blotting}

Extracts of S-layer proteins in $0.1 \%$ SDS were diluted in SDS sample buffer and then heat-denatured $10 \mathrm{~min}$ at $95^{\circ} \mathrm{C}$. One-dimensional polyacrylamide gel electrophoresis (10.0\%) was conducted according to Laemmli (Laemmli, 1970) on a Mini-PROTEAN ${ }^{\circledR}$ Tetra Cell (Bio-Rad, Hercules, CA, United 
States) and the gels were stained using Coomassie Blue BioSafe reagent (Bio-Rad). Alternatively, S-layer protein associated extracts were separated by $10 \%$ SDS-PAGE and transferred to PVDF membranes (GE Healthcare). After blocking with 3\% nonfat dry milk diluted in TBS (Tris $10 \mathrm{mM}, \mathrm{NaCl} 0.15 \mathrm{M}, 0.3 \%$ tween 20), the membranes were incubated overnight at $4^{\circ} \mathrm{C}$ with primary antibodies purified from rabbit sera (AGRO-BIO, France). These were obtained by injecting the following $\operatorname{sipB}$ peptide to rabbits: IDATVDKQNSKGGFGWGG and used at the dilution 1:10,000. After washing, membranes were incubated with secondary antibodies: anti-rabbit IgG conjugated with horseradish peroxidase (1:15,000, AGRO-BIO, France) for $2 \mathrm{~h}$ at room temperature. Bound antibodies were visualized with ECL Plus system (GE Healthcare, Vélizy, France) and blots were scanned using the Syngene GBox (Ozyme, Saint-Quentin-enYvelines, France). The specificity of anti-SlpB western blotting was checked (Supplementary Figure S1). A single band was observed only in strains expressing SlpB and the labeling pattern was distinct from that of anti-SlpA and anti-SlpE western blotting.

\section{Data Analysis}

All the experiments were performed with three technical replicates and three biological replicates, and the results were expressed as means \pm standard deviations (SD). Statistical analyses were performed in R Statistical Software (Foundation for Statistical Computing, Vienna, Austria) using ANOVA with Tukey post hoc analyses for multiple comparisons.

\section{RESULTS}

\section{Surface Layer Associated Proteins and Adhesion to Cultured Human Colon Cells Are Variable among Strains of $P$. freudenreichii}

Seven strains of $P$. freudenreichii from the CIRM-BIA collection (Table 1), CB 118, CB 121, CB 129, CB 134, CB 136, CB 508, and $\mathrm{CB} 527$, have been selected based on preliminary proteomic screening as they all displayed different surface proteomes as shown by their S-layer associated protein pattern after guanidine treatment (Figure 1A). The five proteins, previously identified in CB 129 (SlpA, SlpB, SlpE, InlA, and LspA, see Le Maréchal et al., 2015), and thought to play a role in interactions with the host, are indicated in the figure. Preliminary results pointed out SlpB as a potential key surface protein in P. freudenreichii. We thus developped antibodies in order to confirm this. Western blot analysis using these antibodies further confirmed variability of surface proteins (Figure 1B). SlpB was detected in four strains out of seven, with different intensities. The variability of S-layer associated proteins suggested possible variations regarding interactions with host cells. The seven strains were further compared with respect to adhesion to HT-29 cultured colon cells (Figure 1C). The CB129 strain, exhibited the highest adhesion rate (6.44 CFU/1 HT-29 cell) and was used as the reference (100\% adhesion) for comparison with the other strains

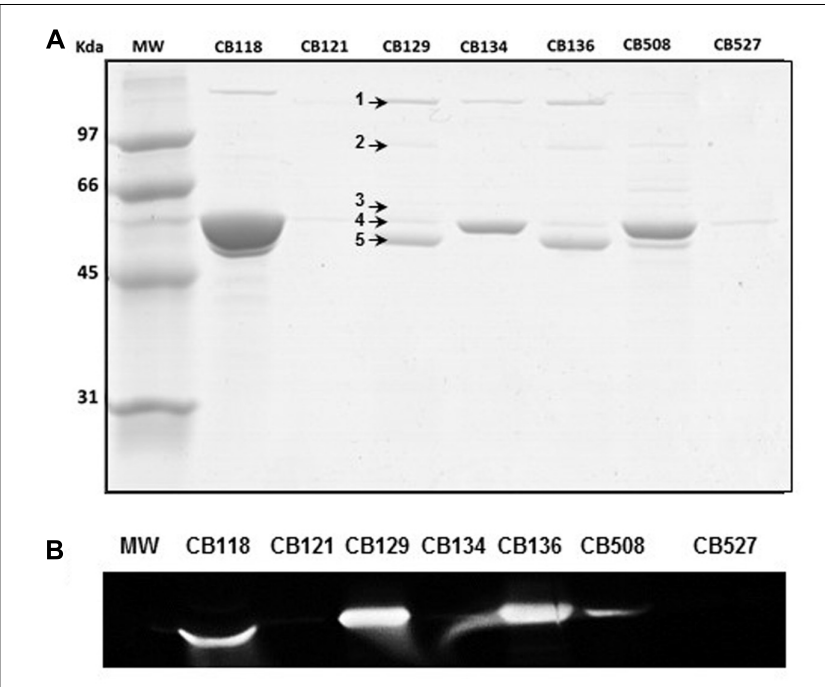

C

Adhesion of $P$. freudenreichii strains

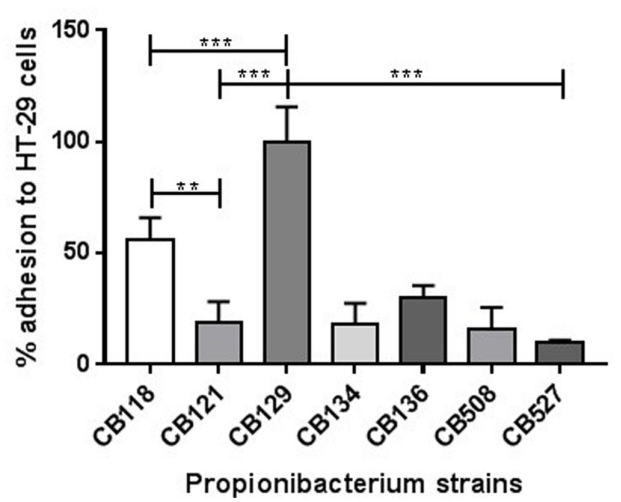

FIGURE 1 | Variability of surface proteome and of adhesion among strains of Propionibacterium freudenreichii. (A) Guanidine-extracted surface layer associated proteins are variable. Seven strains of $P$. freudenreichii were cultured in milk ultrafiltrate and subjected to guanidine-extraction followed by SDS-PAGE (10\%) gel electrophoretic analysis of the extracts. Gels were either Coomassie-Blue-stained (A) or transferred to a PVDF membrane. Surface proteins previously identified by mass spectrometry as InIA, LspA, SIpE, SIpA and SlpB in strain CB129 are indicated by 1, 2, 3, 4, and 5, respectively. (B) Western Blotting detection of surface layer protein SIpB. PVDF membranes were treated using rabbit antibodies raised against P. freudenreichii surface layer protein SIpB. (C) Adhesion to cultured human colon epithelial cells is variable. HT-29 cells were cultured to confluence in DMEM prior to co-incubation. Each well $\left(1 \times 10^{6} \mathrm{HT}-29\right.$ cells) was added with $1 \times 10^{8}$ colony-forming unit (CFU) of $P$. freudenreichii. Co-incubation was 60 min at $37^{\circ} \mathrm{C}$ in DMEM. After thorough washing with PBS, adhered bacteria were enumerated by CFU plate counting in trypsinized cells. Numbers of the strains used are indicated. Asterisks represent statistically significant differences between strains and were indicated as follows: ${ }^{*} p<0.05$; ${ }^{* *} p<0.01 ;{ }^{* * *} p<0.001$. Adhesion is presented as a percent of the reference CB129 P. freudenreichii strain. Original gels and western blots, uncropped, are provided in Supplementary Figure S1.

$(100.0 \% \pm 17)$. Indeed, CB129 showed a significant difference $(p<0.001)$ with the other $P$. freudenreichii strains tested under the same experimental conditions. The CB118 strain exhibited a 
lower but significant adherence percentage of $56.0 \% \pm 10.0$ and also displayed SlpB. All the other strains exhibited low adhesion rates without significant differences among them, although CB136 (30.0\% \pm 5.0$)$, which also displays SlpB, tended to be more adhesive than the rest of this subset. Finally, the lowest adhesion rate was recorded for CB527, 10.0\% \pm 1.0 , for which no surface protein was detected, in accordance with (Deutsch et al., 2017). Different propionibacteria: HT-29-cells ratios were tested for adhesion (100:1, 500:1, and 1,000:1, in technical and biological triplicates) with similar results in adhesion rates ranking. At the MOI of 100:1 used in this study, no internalization of $P$. freudenreichii was observed (data not shown) using the gentamicin method used by our team to monitor staphylococci internalization (Bouchard et al., 2013).

\section{P. freudenreichii CB129 Interacts with Cultured Human Colon Cells}

Adhesion of $P$. freudenreichii to HT-29 cells being demonstrated, we further looked at such an interaction, using three-dimensional confocal microscopy. As seen in Figure 2A, the sections close to the bottom of the slide culture chamber mainly exhibited the blue fluorescence of the HT-29 nuclei, stained with DAPI, a poorly fluorescent cytoplasm, surrounded by a red-stained plasma membrane (lowest images in Figure 2A). Ascending within this "z-stack," higher sections showed dots with intense red fluorescence, corresponding to cell membranes, indicative of colonocytes microvilli constituting the brush border. Higher sections showed co-localization of these red dots with greenfluorescent propionibacteria, caused by CFSE metabolization within propionibacteria. More precisely, propionibacteria appeared as aggregates, in the intercellular space of the epithelial HT-29 monolayer. This localization of propionibacteria in contact with cells is further illustrated in the reconstituted 3-D view (Figure 2B). Interaction of propionibacteria with cultured human colonocytes was further illustrated by scanning electron microscopy of co-cultures on cell culture inserts (Figure 2C). This revealed localization of propionibacteria at the surface of cells, in contact with the brush border.

\section{P. freudenreichii CB129 Adhesion to Cultured Human Colon Cells Involves Surface Proteins}

To determine whether the presence of surface proteins is involved in the adhesion of P. freudenreichii to HT-29 cells, the method

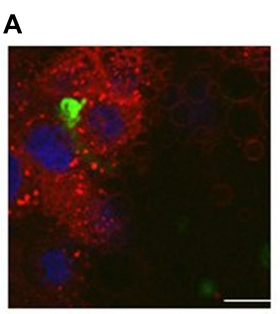

Scale bar $=10 \mu \mathrm{m}$

B

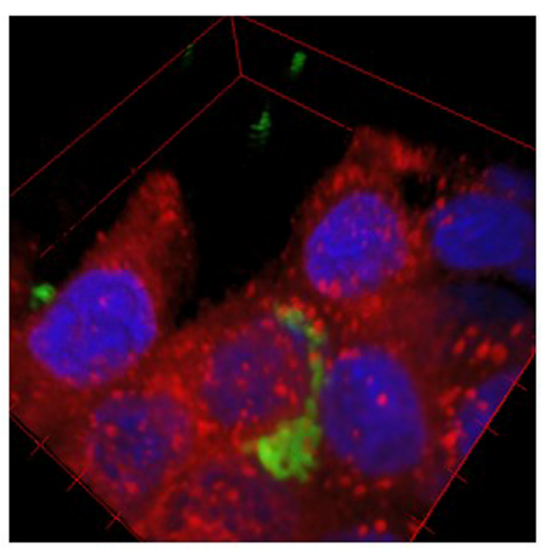

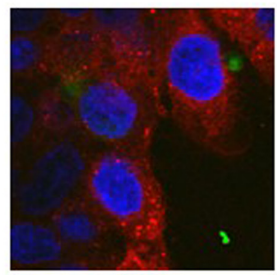

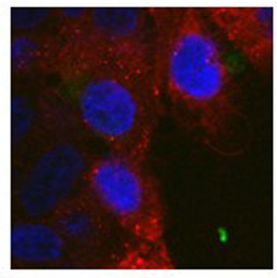

C

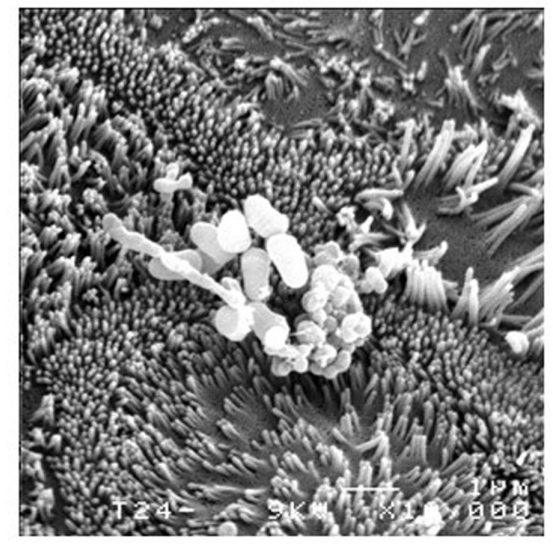

FIGURE 2 | Microscopy imaging of P. freudenreichii Centre International de Ressources Microbiennes-Bactéries d'Intérêt Alimentaire (CIRM-BIA) 129 adhesion to cultured human colon epithelial cells. HT-29 cells were cultured to confluence in DMEM on a slide chamber prior to interaction. $P$. freudenreichii was cultured in fermented milk ultrafiltrate prior to intracellular labeling of live bacteria using CFSE. Labeled bacteria were then co-incubated with colon cells in a slide chamber prior to washing with PBS and to staining of plasma membrane using Rh-DOPE and mounting in DAPI-containing mounting medium. (A,B) Blue fluorescence evidences colon cells nuclei, red fluorescence their plasma membrane and green fluorescence CFSE-labeled propionibacteria. (A) Z-stack, i.e., confocal images acquired at different " $Z$ " altitudes in the labeled preparation. (B) Reconstituted 3-D image showing a cluster of propionibacteria at surface of cells. (C) Scanning electron microscopy observation of propionibacteria adhesion to cultured colon epithelial cells. The same co-incubation was performed in a polycarbonate membrane cell culture insert prior to fixation and scanning electron microscopy observation. 
of enzymatic shaving using trypsin was applied, before adhesion assay. A significant reduction $(p<0.001)$ was observed in the adhesion rate: $21.77 \pm 8.10 \%$ for shaved bacteria, compared to the positive control consisting of propionibacteria (Figure 3A). Western blot analysis also indicated absence of SlpB at the surface of $P$. freudenreichii as a result of shaving (Figure 3B). To further confirm the role of surface proteins in adhesion, P. freudenreichii CB129 cells, shaved or not, were incubated with $50 \mu \mathrm{g}$ of extracted surface proteins. This guanidine extract from the CB129 strain was previously dialyzed against PBS and quantified by Bradford assay. It contained the five proteins (SlpA, SlpB, SlpE, InlA, and LspA, see Figure 1A) in PBS buffer $\mathrm{pH}$ 7.4. Adhesion assay was then conducted. This incubation increased the rate of adhesion of $P$. freudenreichii CB129 to HT-29 cells, from $100.00 \% \pm 8.93$ to $317.07 \% \pm 46.68$. Furthermore, adhesion rate, which was strongly diminished by enzymatic shaving $(33.99 \% \pm 14.30)$, was restored by this incubation $(157.44 \% \pm 18.31$, Figure 3C). This further experiment confirmed the key role of at least one of these surface proteins in adhesion.

\section{Surface Protein SIpB Plays a Key Role in Adhesion to Cultured Human Colon Cells}

In a second approach to inhibit adhesion and to precise the role of specific surface proteins, $P$. freudenreichii was incubated with antibodies raised against $\mathrm{SlpB}$, at a dilution of 1:10,000, before adhesion assay. This resulted in a significant reduction following incubation with the anti-SlpB antibodies 39.95\% \pm 6.92 $(p<0.001)$, (Figure 4A). We then further focused on SlpB and inactivated its gene in $P$. freudenreichii CB129. The mutant $P$. freudenreichii CB129 $\Delta s l p B$ was obtained by insertion of the pUC: $\triangle \operatorname{slp} B: C m \mathrm{R}$ suicide plasmid as described in the "Materials and Methods" section (Supplementary Figure S2). The stability of the mutant was validated after growth in the presence or absence of chloramphenicol by checking for the absence of SlpB production. As shown in Figure 4B, one protein band (about $55 \mathrm{kDa}$ in size) was lacking in the mutant S-layer associated proteins guanidine extract (line 2), when compared to the WT parental strain (line 1). Western Blot analysis using antibodies raised against the SlpB protein (Figure 4C) confirmed that this protein was effectively mutated in the mutant (line 2) when compared to the parental strain (line 1). Efficient and specific inactivation of the $\operatorname{slp} B$ gene was further established by mass spectrometry analysis of guanidine-extracted S-layer proteins. Indeed, the SlpA, SlpB, and SlpE proteins were clearly identified in the WT CB129 strains, while only SlpA and SlpE were detected in the mutant $P$. freudenreichii CB129 $\Delta s l p B$ strain (Table 2).

Adhesion to HT-29 cells was then assessed by CFU counting and the mutant CB129 $\Delta s$ lpB strain was impaired in adhesion $(20.66 \% \pm 8.32)$ when compared to the WT control $(100.00 \% \pm 7.37)$ (Figure 4A, $p<0.001)$. To confirm this result, adhesion of $P$. freudenreichii to HT-29 cells, using CFSEstained propionibacteria, was quantified by flow cytometry. Cells were treated with CFSE-labeled propionibacteria, WT or CB129 $\Delta s l p B$ mutant, for $1 \mathrm{~h}$, before cytometric monitoring of cell fluorescence (Figures 4D-F). A shift in fluorescence intensity

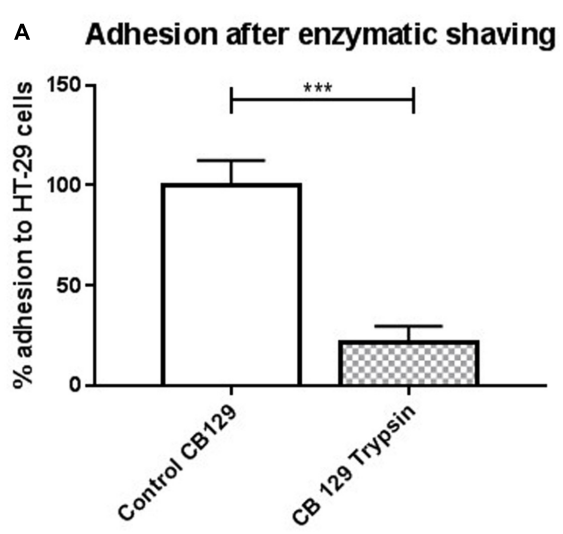

B

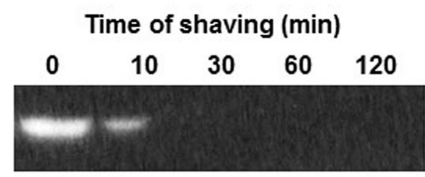

c Adhesion with S-layer Extract

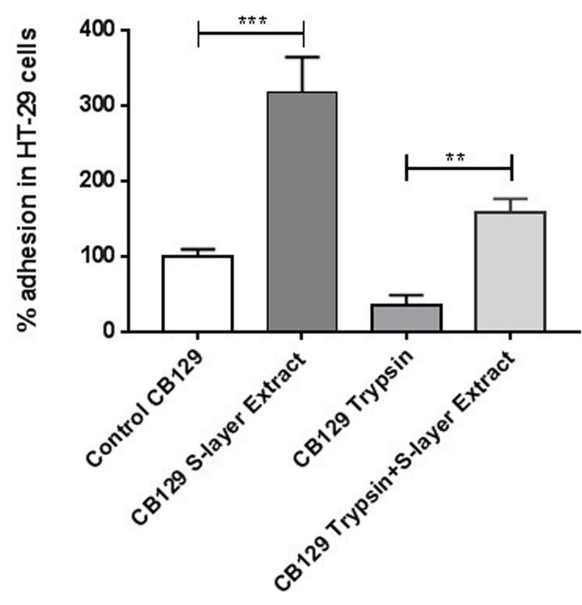

FIGURE 3 | Involvement of $P$. freudenreichii surface proteins in adhesion. (A) Trypsin shaving reduces $P$. freudenreichii CIRM-BIA 129 adhesion. Human colon cells were cultured in DMEM prior to co-incubation with propionibacteria. Used propionibacteria were either untreated (control) or submitted to trypsin shaving of surface proteins for $60 \mathrm{~min}$ (trypsin). Adhered bacteria were enumerated by CFU plate counting in trypsinized cells. (B) Trypsin shaving reduces presence of SlpB protein in $P$. freudenreichii CIRM-BIA 129 in different times of incubation. P. freudenreichii CIRM-BIA 129 show after different incubations time with trypsin $\left(T_{\text {zero }}\right.$ min, $T_{30} \mathrm{~min}, \mathrm{~T}_{60} \mathrm{~min}$, and $T_{120} \mathrm{~min}$ ) a decreased amount of SIpB in Western Blot analysis with anti-SIpB antibodies. (C) Addition of extracted surface layer proteins enhances P. freudenreichii CIRM-BIA 129 adhesion. Human colon cells were cultured prior to co-incubation with propionibacteria. Used propionibacteria were either shaved for $60 \mathrm{~min}$ (trypsin) or untreated (control). They were then added with surface layer guanidine extract (50 $\mu \mathrm{g}$ of proteins) or not. Adhesion was quantified by plate CFU counting of propionibacteria after trypsinization of colon cells. Adhesion is presented as a percent of the reference CIRM-BIA 129 P. freudenreichii strain. Asterisks represent statistically significant differences between strains and were indicated as follows: $* p<0.05$; ${ }^{* *} p<0.01$; ${ }^{* *} p<0.001$. Adhesion is presented as a percent of the reference CB129 $P$. freudenreichii strain. 

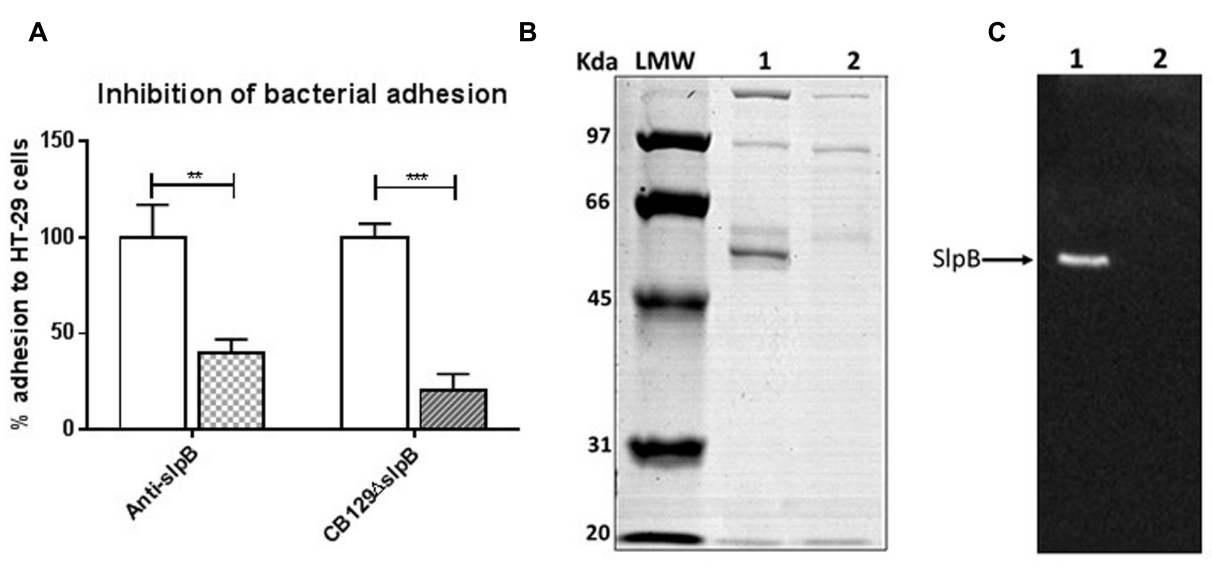

D

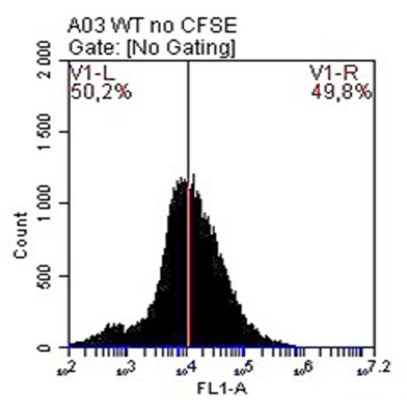

E

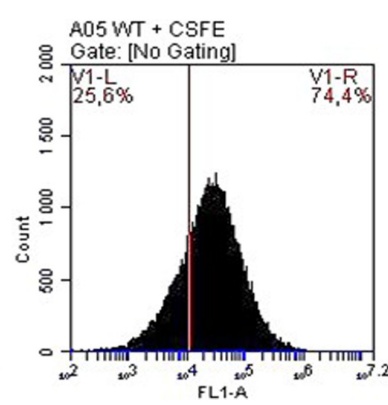

F

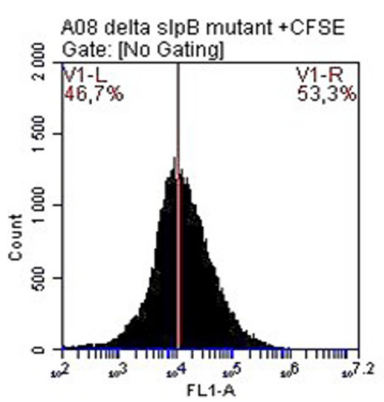

FIGURE 4 | Key role of surface layer protein SIpB in adhesion. (A) Antibodies reduce P. freudenreichii adhesion and so does s/pB gene inactivation. Human colon cells were cultured in DMEM prior to co-incubation with propionibacteria. P. freudenreichii CIRM-BIA 129 was treated with antibodies raised against SIpB prior to adhesion assay. As an alternative, the s/pB gene was inactivated in P. freudenreichii CIRM-BIA 129 prior to adhesion assay. Adhesion is presented as a percent of the reference CB129 P. freudenreichii strain. (B) Guanidine-extracted surface layer associated proteins were compared by SDS-PAGE in P. freudenreichii CIRM-BIA 129 wild-type (line 1) and in the corresponding mutant CB129 $\Delta$ s/pB (line 2). (C) The corresponding PVDF membrane was subjected to Western Blotting using rabbit antibodies raised against $P$. freudenreichii surface layer protein SIpB (B). (D,E) Fluorescently labeled live $P$. freudenreichii CIRM-BIA 129 adheres to cultured human colon epithelial HT-29 cells. The adhesion of CFSE-labeled propionibacteria was detected by the shift in FL1 intensity (E), compared to HT-29 cells with unlabelled propionibacteria (D). Cells $\left(10^{6}\right)$ were co-incubated with $10^{8} \mathrm{CFU}$ of CFSE-stained propionibacteria for $1 \mathrm{~h}$. At least 50.000 cells per sample were analyzed. As an alternative, labeled $P$. freudenreichii mutant CB129 $\Delta$ s/pB was co-incubated with HT-29 cells (F). Original gels and western blots, uncropped, are provided in Supplementary Figure S1. Asterisks represent statistically significant differences between strains and were indicated as follows: ${ }^{*} p<0.05 ;{ }^{* *} p<0.01$; ${ }^{* * *} p<0.001$. Adhesion is presented as a percent of the reference CB129 P. freudenreichii strain.

TABLE 2 | Surface-layer proteins identified after Guanidine Hydrochloride extraction.

\begin{tabular}{|c|c|c|c|c|c|c|c|}
\hline \multirow[b]{2}{*}{ Gene name } & \multirow[b]{2}{*}{ Locus tag } & \multicolumn{3}{|c|}{ Wild-type strain } & \multicolumn{3}{|c|}{ Delta SIpB strain } \\
\hline & & $\log (e-v a l u e)^{a}$ & Cover $(\%)^{b}$ & Peptides $^{c}$ & $\log (e-v a l u e)^{a}$ & Cover $(\%)^{b}$ & Peptides $^{c}$ \\
\hline SlpB & PFCIRM129_00700 & -263.2 & 74 & 34 & 0 & 0 & 0 \\
\hline SlpE & PFCIRM129_05460 & -125.6 & 50 & 19 & -138.8 & 55 & 18 \\
\hline SlpA & PFCIRM129_09350 & -174.3 & 75 & 24 & -143.5 & 68 & 22 \\
\hline
\end{tabular}

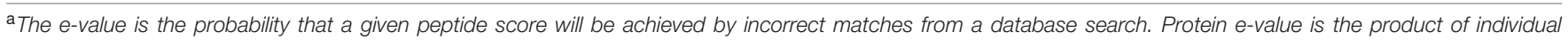

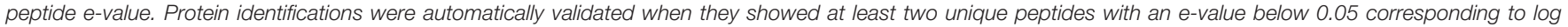

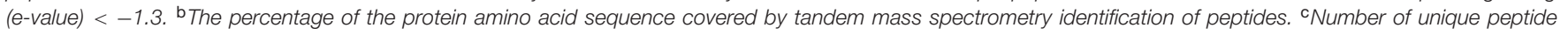
sequence identified with an individual e-value $<0.01$ for this protein.

(FL1) was observed as a result of fluorescent $P$. freudenreichii CB129 adhesion to cells (Figure 4E) when compared with control cells without bacteria (Figure 4D). This indicates an increase of fluorescence emission at $488 \mathrm{~nm}$, corresponding to 6-carboxyfluorescein succinimidyl harbored by adhering bacteria, as described previously for lactobacilli (Tiptiri-Kourpeti et al., 2016). By contrast, the mutant CB129 $\Delta s l p B$ strain failed to reproduce this fluorescence shift in HT-29 cells, and the pattern (Figure 4F) was similar to that of HT-29 without bacteria (Figure 4A). Altogether, these results confirm the key role of the 
SlpB surface protein in adhesion of $P$. freudenreichii to HT-29 cells.

\section{DISCUSSION}

Adhesion is a key determinant of host/bacterium interactions, whether pathogenic or probiotic. Adhesion of probiotic bacteria to host intestinal cells may favor important effects including modulation of mucus secretion (Mack et al., 2003), of defensin production (Schlee et al., 2007, 2008), or the local action of beneficial metabolites. It can improve competitive exclusion of pathogens by adhesion competition (Servin, 2004; Lebeer et al., 2008) and constitutes a key factor for several clinical applications of probiotics in the prevention and treatment of gastrointestinal disorders and of IBD. It may involve, on the bacterial side, various microorganism-associated molecular patterns (MAMPs) including flagellin, fimbriae (also called pili) or other surface proteins including moonlighting proteins and S-layer proteins (Lebeer et al., 2010).

Surface-layer proteins constitute a field of research that deserves further investigation. Although anchored to the cell wall via conserved SLH domains, their extracellular protruding part is highly variable, poorly conserved amongst bacterial species and strains. A previous paradigm described S-layers as a macromolecular paracrystalline network formed by the selfassembly of numerous copies of one monomeric protein or glycoprotein and constituting an extracellular S-layer in many bacteria (Sleytr, 1997; Sára and Sleytr, 2000). This was later challenged by studies on Lactobacillus acidophilus showing that a S-layer can contain various S-layer proteins or SLPs (Hymes et al., 2016). These proteins are in fact versatile molecules that may play an important role in growth and survival, maintenance of cell integrity, enzyme display, molecular sieving, co-aggregation, immunomodulation, as well as adhesion and persistence within the animal host (Lebeer et al., 2010; Fagan and Fairweather, 2014). In $P$. freudenreichii, such proteins were shown to be involved in immunomodulatory interactions with the host (Le Maréchal et al., 2015), a property highly strain-dependent (Mitsuyama et al., 2007; Foligné et al., 2010, 2013). Indeed, a functional role in immunomodulation by $P$. freudenreichii was recently attributed to a set of proteins: SlpB, SlpE, two putative S-layer proteins with SLH domains, and HsdM3, predicted as cytoplasmic (Deutsch et al., 2017).

Variability of $P$. freudenreichii surface proteins may thus be related to variability in functional properties. In this context, we have selected in the present work seven $P$. freudenreichii strains with different patterns evidenced in a preliminary study.

We confirm here that $P$. freudenreichii S-layer proteins are variable, and so is its ability to adhere to cultured human epithelial cells, as determined by quantitative culturing (Mack et al., 1999), which suggests a functional link between variations in the surface protein pattern. P. freudenreichii CIRM-BIA 129, shown to alleviate symptoms of acute colitis in mice, displays S-layer associated proteins and the highest adhesion ability, whatever the bacteria/cell ratio $(100: 1 ; 500: 1$; and 1,000:1). Moreover, at a ratio of 100/1, no internalization was observed.
This suggests that propionibacteria either do not internalize into cultured HT-29 cells, or do not suvive within the cells. Cultured colon epithelial HT-29 cells do not produce mucus in our conditions. This suggests that $P$. freudenreichii interacts with epithelial cell surface compounds rather than mucins, a property previously reported for the probiotic L. acidophilus (Johnson et al., 2013). Interestingly, CB129 was shown to restore expression of ZO-1, a key protein of tight junctions which expression was impaired in colitis (Plé et al., 2015), as part of its anti-inflammatory effect. Adhesion close to these junctions may favor the local action of propionibacteria via local release of propionate, the major metabolite of propionibacteria, which was shown to improve intestinal barrier function and to restore expression of ZO-1 in DSS-treated mice (Tong et al., 2016). Accordingly, protection toward inflammation-induced barrier defects was reported for the probiotic product VSL\#3 (Krishnan et al., 2016).

Enzymatic shaving of surface proteins reduced adhesion and was previously shown to hydrolyze at least 16 distinct proteins (Le Maréchal et al., 2015). Dramatic inhibition of adhesion was observed following blockage with antibodies raised against SlpB. Interruption of the $\operatorname{slp} B$ gene in CB129 strain also resulted in a drastic reduction $(P<0.01)$ in adhesion. Moreover, addition of purified S-layer proteins restored the adhesion that was suppressed in $P$. freudenreichii by enzymatic shaving. Altogether, these results indicate a role of $P$. freudenreichii S-layer protein, including SlpB, in adhesion, as was reported for the SlpA protein in L. acidophilus NCFM (Buck et al., 2005).

This study evidenced a key role of one of the P. freudenreichii S-layer proteins in adhesion to human intestinal cells. Understanding determinants of probiotic action is a key challenge. It opens new avenues for the screening of most promising propionibacteria strains, by monitoring their expression, and for the development of new functional products containing them. It is particularly relevant in the context of pathogens competitive exclusion and inflammation remediation.

\section{AUTHOR CONTRIBUTIONS}

GJ and FdC designed the research. GJ, YL, and VA supervised the work. FdC, HR, SH, FG, MD, SD, and JJ took part to the experiments. FdC and GJ wrote the manuscript. YL and VA corrected the manuscript.

\section{FUNDING}

This work was supported by Conselho Nacional de Desenvolvimento Científico e Tecnológico (CNPq, Brazil). $\mathrm{HR}$ is the recipient of a doctoral fellowship from Bba, FG from Biodis.

\section{ACKNOWLEDGMENTS}

The authors thank Sandrine Parayre for expert technical assistance and Clément Thal for useful discussions and advices. 


\section{SUPPLEMENTARY MATERIAL}

The Supplementary Material for this article can be found online at: http://journal.frontiersin.org/article/10.3389/fmicb. 2017.01033/full\#supplementary-material

FIGURE S1 | Specificity of the anti-SlpB antibodies. The whole gels (I, II) and whole blots (II, IV) corresponding to Figures 1, $\mathbf{4}$ are shown. A single band reacting with anti-SIpB antibodies is evidenced. Moreover, specific inactivation of slpB gene leads to disappearance of this reactive band (IV). Finally, western blot using anti-SIpB antibodies reveals the SIpB protein only in strains which harbor the corresponding slpB gene, as indicated by the Table (V). In supplemental western

\section{REFERENCES}

Belkaid, Y., and Hand, T. (2014). Role of the microbiota in immunity and inflammation. Cell 157, 121-141. doi: 10.1016/j.cell.2014.03.011

Bensi, G., Mora, M., Tuscano, G., Biagini, M., Chiarot, E., Bombaci, M., et al. (2012). Multi high-throughput approach for highly selective identification of vaccine candidates: the group a Streptococcus case. Mol. Cell. Proteomics 11, M111.015693. doi: 10.1074/mcp.M111.015693

Berlec, A., Zadravec, P., Jevnikar, Z., and Štrukelj, B. (2011). Identification of candidate carrier proteins for surface display on Lactococcus lactis by theoretical and experimental analyses of the surface proteome. Appl. Environ. Microbiol. 77, 1292-1300. doi: 10.1128/AEM.02102-10

Bøhle, L. A., Riaz, T., Egge-Jacobsen, W., Skaugen, M., Busk, ØL., Eijsink, V. G., et al. (2011). Identification of surface proteins in Enterococcus faecalis V583. BMC Genomics 12:135. doi: 10.1186/1471-2164-12-135

Bouchard, D. S., Rault, L., Berkova, N., Le Loir, Y., and Even, S. (2013). Inhibition of Staphylococcus aureus invasion into bovine mammary epithelial cells by contact with live Lactobacillus casei. Appl. Environ. Microbiol. 79, 877-885. doi: 10.1128/AEM.03323-12

Bouglé, D., Roland, N., Lebeurrier, F., and Arhan, P. (1999). Effect of propionibacteria supplementation on fecal bifidobacteria and segmental colonic transit time in healthy human subjects. Scand. J. Gastroenterol. 34, 144-148.

Bryson, K., Loux, V., Bossy, R., Nicolas, P., Chaillou, S., van de Guchte, M., et al. (2006). AGMIAL: implementing an annotation strategy for prokaryote genomes as a distributed system. Nucleic Acids Res. 34, 3533-3545. doi: 10.1093/ nar/gkl471

Buck, B. L., Altermann, E., Svingerud, T., and Klaenhammer, T. R. (2005). Functional analysis of putative adhesion factors in Lactobacillus acidophilus NCFM. Appl. Environ. Microbiol. 71, 8344-8351. doi: 10.1128/AEM.71.12. 8344-8351.2005

ClinicalTrials.gov (2017). Interest of Propionibacterium Freudenreichii for the Treatment of Mild to Moderate Ulcerative Colitis. Available at: https:// clinicaltrials.gov/ct2/show/NCT02488954 [accessed October 11 2016].

Cousin, F. J., Foligné, B., Deutsch, S.-M., Massart, S., Parayre, S., Le Loir, Y., et al. (2012a). Assessment of the probiotic potential of a dairy product fermented by Propionibacterium freudenreichii in piglets. J. Agric. Food Chem. 60, 7917-7927. doi: $10.1021 /$ jf302245m

Cousin, F. J., Jouan-Lanhouet, S., Dimanche-Boitrel, M.-T., Corcos, L., and Jan, G. (2012b). Milk fermented by Propionibacterium freudenreichii induces apoptosis of HGT-1 human gastric cancer cells. PLoS ONE 7:e31892. doi: 10.1371/journal. pone.0031892

Cousin, F. J., Mater, D. D. G., Foligne, B., and Jan, G. (2010). Dairy propionibacteria as human probiotics: a review of recent evidence. Dairy Sci. Technol. 91, 1-26. doi: $10.1051 /$ dst $/ 2010032$

de Souza, H. S. P., and Fiocchi, C. (2016). Immunopathogenesis of IBD: current state of the art. Nat. Rev. Gastroenterol. Hepatol. 13, 13-27. doi: 10.1038/ nrgastro.2015.186

Deutsch, S. M., Mariadassou, M., Nicolas, P., Parayre, S., Le Guellec, R., Chuat, V., et al. (2017). Identification of proteins involved in the anti-inflammatory properties of Propionibacterium freudenreichii by means of a multi-strain study. Sci. Rep 7:46409. doi: 10.1038/srep46409 blots of the same extracts $(\mathrm{VI})$, sera directed against SIpA and SIpE evidence a distinct pattern. In particular, the two close Coomassie-stained bands, 58 and $56 \mathrm{kDa}$, were identified by western blot (this work) and by mass spectrometry (Le Maréchal et al., 2015) as SIpA and slpB, respectively.

FIGURE S2 | Interruption of $s / p B$ gene using suicide vector pUC: $\triangle \mathrm{s} / \mathrm{pB}: C m R$. (A-C) Schematic view of homologous recombination producing a mutant $C B$ $128 \Delta s / p B$. Disruption of $s / p B$ gene in CB 129 WT by suicide vector pUC:CmR harboring $520-b p$ of $s / p B$. Mutant strain show a chloramphenicol resistance by insertion of cassette containing $\mathrm{CmR}$. (D) Targeting sequence used to inactivate. Partial sequence of s/pB gene in CB $129 \mathrm{WT}$ and sequence used to homologous recombination (red). The primers annealing site are indicated as underlined bases and oligonucleotides sequence are shown in figure.

Deutsch, S.-M., Parayre, S., Bouchoux, A., Guyomarc'h, F., Dewulf, J., DolsLafargue, M., et al. (2012). Contribution of surface $\beta$-glucan polysaccharide to physicochemical and immunomodulatory properties of Propionibacterium freudenreichii. Appl. Environ. Microbiol. 78, 1765-1775. doi: 10.1128/AEM. 07027-11

Fagan, R. P., and Fairweather, N. F. (2014). Biogenesis and functions of bacterial S-layers. Nat. Rev. Microbiol. 12, 211-222. doi: 10.1038/nrmicro3213

Foligné, B., Breton, J., Mater, D., and Jan, G. (2013). Tracking the microbiome functionality: focus on Propionibacterium species. Gut 62, 1227-1228. doi: 10.1136/gutjnl-2012-304393

Foligné, B., Deutsch, S.-M., Breton, J., Cousin, F. J., Dewulf, J., Samson, M., et al. (2010). Promising immunomodulatory effects of selected strains of dairy propionibacteria as evidenced in vitro and in vivo. Appl. Environ. Microbiol. 76, 8259-8264. doi: 10.1128/AEM.01976-10

Food and Agriculture Organization of the United Nations and World Health Organization (eds) (2002). Probiotics in Food: Health and Nutritional Properties and Guidelines for Evaluation. Rome: Food and Agriculture Organization.

Havenaar, R., Brink, B. T., and Huisin't Veld, J. H. J. (1992). "Selection of strains for probiotic use," in Probiotics, eds R Fuller (Dordrecht: Springer), 209-224.

Hojo, K., Yoda, N., Tsuchita, H., Ohtsu, T., Seki, K., Taketomo, N., et al. (2002). Effect of ingested culture of Propionibacterium freudenreichii ET-3 on fecal microflora and stool frequency in healthy females. Biosci. Microflora 21, 115-120. doi: 10.12938/bifidus1996.21.115

Huang, Y., and Adams, M. C. (2003). An in vitro model for investigating intestinal adhesion of potential dairy propionibacteria probiotic strains using cell line C2BBe1. Lett. Appl. Microbiol. 36, 213-216.

Hymes, J. P., Johnson, B. R., Barrangou, R., and Klaenhammer, T. R. (2016). Functional analysis of an S-Layer-Associated fibronectin-binding protein in Lactobacillus acidophilus NCFM. Appl. Environ. Microbiol. 82, 2676-2685. doi: 10.1128/AEM.00024-16

Jan, G., Belzacq, A.-S., Haouzi, D., Rouault, A., Métivier, D., Kroemer, G., et al. (2002). Propionibacteria induce apoptosis of colorectal carcinoma cells via short-chain fatty acids acting on mitochondria. Cell Death. Differ. 9, 179-188. doi: 10.1038/sj.cdd.4400935

Johnson, B., Selle, K., O’Flaherty, S., Goh, Y. J., and Klaenhammer, T. (2013). Identification of extracellular surface-layer associated proteins in Lactobacillus acidophilus NCFM. Microbiol. Read. Engl. 159, 2269-2282. doi: 10.1099/mic.0. 070755-0

Kaneko, T. (1999). A novel bifidogenic growth stimulator produced by Propionibacterium freudenreichii. Biosci. Microflora 18, 73-80. doi: 10.12938/ bifidus1996.18.73

Krishnan, M., Penrose, H. M., Shah, N. N., Marchelletta, R. R., and McCole, D. F. (2016). VSL\#3 probiotic stimulates T-cell Protein tyrosine phosphatasemediated recovery of IFN- $\gamma$-induced intestinal epithelial barrier defects. Inflamm. Bowel Dis. 22, 2811-2823. doi: 10.1097/MIB.0000000000000954

Laemmli, U. K. (1970). Cleavage of structural proteins during the assembly of the head of bacteriophage T4. Nature 227, 680-685. doi: 10.1038/227680a0

Lan, A., Lagadic-Gossmann, D., Lemaire, C., Brenner, C., and Jan, G. (2007). Acidic extracellular $\mathrm{pH}$ shifts colorectal cancer cell death from apoptosis to necrosis upon exposure to propionate and acetate, major end-products of the human probiotic propionibacteria. Apoptosis Int. J. Program. Cell Death 12, 573-591. doi: 10.1007/s10495-006-0010-3 
Le Maréchal, C., Peton, V., Plé, C., Vroland, C., Jardin, J., Briard-Bion, V., et al. (2015). Surface proteins of Propionibacterium freudenreichii are involved in its anti-inflammatory properties. J. Proteomics 113, 447-461. doi: 10.1016/j.jprot. 2014.07.018

Lebeer, S., Vanderleyden, J., and De Keersmaecker, S. C. J. (2008). Genes and molecules of lactobacilli supporting probiotic action. Microbiol. Mol. Biol. Rev. 72, 728-764. doi: 10.1128/MMBR.00017-08

Lebeer, S., Vanderleyden, J., and De Keersmaecker, S. C. J. (2010). Host interactions of probiotic bacterial surface molecules: comparison with commensals and pathogens. Nat. Rev. Microbiol. 8, 171-184. doi: 10.1038/nrmicro2297

Lortal, S., Rouault, A., Cesselin, B., and Sleytr, U. B. (1993). Paracrystalline surface layers of dairy propionibacteria. Appl. Environ. Microbiol. 59, 2369-2374.

Mack, D. R., Ahrne, S., Hyde, L., Wei, S., and Hollingsworth, M. A. (2003). Extracellular MUC3 mucin secretion follows adherence of Lactobacillus strains to intestinal epithelial cells in vitro. Gut 52, 827-833.

Mack, D. R., Michail, S., Wei, S., McDougall, L., and Hollingsworth, M. A. (1999). Probiotics inhibit enteropathogenic E. coli adherence in vitro by inducing intestinal mucin gene expression. Am. J. Physiol. 276, G941-G950.

Malik, A. C., Reinbold, G. W., and Vedamuthu, E. R. (1968). An evaluation of the taxonomy of Propionibacterium. Can. J. Microbiol. 14, 1185-1191.

Mayrhofer, C., Krieger, S., Allmaier, G., and Kerjaschki, D. (2006). DIGE compatible labelling of surface proteins on vital cells in vitro and in vivo. Proteomics 6, 579-585. doi: 10.1002/pmic.200500104

Michaux, C., Saavedra, L. F. R., Reffuveille, F., Bernay, B., Goux, D., Hartke, A., et al. (2013). Cold-shock RNA-binding protein CspR is also exposed to the surface of Enterococcus faecalis. Microbiol. Read. Engl. 159, 2153-2161. doi: 10.1099/mic.0.071076-0

Mitsuyama, K., Masuda, J., Yamasaki, H., Kuwaki, K., Kitazaki, S., Koga, H., et al. (2007). Treatment of ulcerative colitis with milk whey culture with Propionibacterium freudenreichii. J. Intest. Microbiol. 21, 143-147. doi: 10. $11209 /$ jim. 21.143

Moussavi, M., and Adams, M. C. (2010). An in vitro study on bacterial growth interactions and intestinal epithelial cell adhesion characteristics of probiotic combinations. Curr. Microbiol. 60, 327-335. doi: 10.1007/s00284-009-9545-1

Ouwehand, A. C., Lagström, H., Suomalainen, T., and Salminen, S. (2002). Effect of probiotics on constipation, fecal azoreductase activity and fecal mucin content in the elderly. Ann. Nutr. Metab. 46, 159-162.

Ouwehand, A. C., Tölkkö, S., Kulmala, J., Salminen, S., and Salminen, E. (2000). Adhesion of inactivated probiotic strains to intestinal mucus. Lett. Appl. Microbiol. 31, 82-86.

Plé, C., Breton, J., Richoux, R., Nurdin, M., Deutsch, S.-M., Falentin, H., et al. (2016). Combining selected immunomodulatory Propionibacterium freudenreichii and Lactobacillus delbrueckii strains: reverse engineering development of an anti-inflammatory cheese. Mol. Nutr. Food Res. 60, 935-948. doi: 10.1002/mnfr. 201500580

Plé, C., Richoux, R., Jardin, J., Nurdin, M., Briard-Bion, V., Parayre, S., et al. (2015). Single-strain starter experimental cheese reveals anti-inflammatory effect of Propionibacterium freudenreichii CIRM BIA 129 in TNBS-colitis model. J. Funct. Foods 18(Part A), 575-585. doi: 10.1016/j.jff.2015.08.015

Preising, J., Philippe, D., Gleinser, M., Wei, H., Blum, S., Eikmanns, B. J., et al. (2010). Selection of bifidobacteria based on adhesion and anti-inflammatory capacity in vitro for amelioration of murine colitis. Appl. Environ. Microbiol. 76, 3048-3051. doi: 10.1128/AEM.03127-09

Richoux, R., Faivre, É., and Kerjean, J.-R. (1998). Effet de la teneur en $\mathrm{NaCl}$ sur la fermentation du lactate par Propionibacterium freudenreichii dans des minifromages à pâte cuite. Le Lait 78, 319-331. doi: 10.1051/lait:1998332

Riedel, C. U., Foata, F., Goldstein, D. R., Blum, S., and Eikmanns, B. J. (2006). Interaction of bifidobacteria with Caco-2 cells-adhesion and impact on expression profiles. Int. J. Food Microbiol. 110, 62-68. doi: 10.1016/j. ijfoodmicro.2006.01.040

Rodríguez-Ortega, M. J., Norais, N., Bensi, G., Liberatori, S., Capo, S., Mora, M., et al. (2006). Characterization and identification of vaccine candidate proteins through analysis of the group A Streptococcus surface proteome. Nat. Biotechnol. 24, 191-197. doi: 10.1038/nbt1179

Sára, M., and Sleytr, U. B. (2000). S-Layer proteins. J. Bacteriol. 182, 859-868.
Schlee, M., Harder, J., Köten, B., Stange, E. F., Wehkamp, J., and Fellermann, K. (2008). Probiotic lactobacilli and VSL\#3 induce enterocyte beta-defensin 2. Clin. Exp. Immunol. 151, 528-535. doi: 10.1111/j.1365-2249.2007.03587.x

Schlee, M., Wehkamp, J., Altenhoefer, A., Oelschlaeger, T. A., Stange, E. F., and Fellermann, K. (2007). Induction of human beta-defensin 2 by the probiotic Escherichia coli Nissle 1917 is mediated through flagellin. Infect. Immun. 75, 2399-2407. doi: 10.1128/IAI.01563-06

Seki, K., Nakao, H., Umino, H., Isshiki, H., Yoda, N., Tachihara, R., et al. (2004). Effects of fermented milk whey containing novel bifidogenic growth stimulator produced by propionibacterium on fecal bacteria, putrefactive metabolite, defecation frequency and fecal properties in senile volunteers needed serious nursing-care taking enteral nutrition by tube Feeding. J. Intest. Microbiol. 18, 107-115. doi: 10.11209/jim.18.107

Servin, A. L. (2004). Antagonistic activities of lactobacilli and bifidobacteria against microbial pathogens. FEMS Microbiol. Rev. 28, 405-440. doi: 10.1016/j.femsre. 2004.01.003

Sleytr, U. B. (1997). I. Basic and applied S-layer research: an overview. FEMS Microbiol. Rev. 20, 5-12. doi: 10.1111/j.1574-6976.1997.tb00301.x

Thiel, A., Eikmanns, B., Salminen, S., and Ouwehand, A. C. (2004). In vitro adhesion of propionibacteria to human intestinal mucus [dairy products]. Ital. J. Food Sci. Available at: http://agris.fao.org/agris-search/search.do?recordID= IT2005600093 [Accessed October 11, 2016].

Thierry, A., Richoux, R., and Kerjean, J.-R. (2004). Isovaleric acid is mainly produced by Propionibacterium freudenreichii in Swiss cheese. Int. Dairy J. 14, 801-807. doi: 10.1016/j.idairyj.2004.02.002

Tiptiri-Kourpeti, A., Spyridopoulou, K., Santarmaki, V., Aindelis, G., Tompoulidou, E., Lamprianidou, E. E., et al. (2016). Lactobacillus casei exerts anti-proliferative effects accompanied by apoptotic cell death and up-regulation of TRAIL in colon carcinoma cells. PLOS ONE 11:e0147960. doi: 10.1371/journal.pone.0147960

Tong, L.-C., Wang, Y., Wang, Z.-B., Liu, W.-Y., Sun, S., Li, L., et al. (2016). Propionate ameliorates dextran sodium sulfate-induced colitis by improving intestinal barrier function and reducing inflammation and oxidative stress. Front. Pharmacol. 7:253. doi: 10.3389/fphar.2016.00253

Tuomola, E. M., Ouwehand, A. C., and Salminen, S. J. (1999). Human ileostomy glycoproteins as a model for small intestinal mucus to investigate adhesion of probiotics. Lett. Appl. Microbiol. 28, 159-163.

van de Guchte, M., Chaze, T., Jan, G., and Mistou, M.-Y. (2012). Properties of probiotic bacteria explored by proteomic approaches. Curr. Opin. Microbiol. 15, 381-389. doi: 10.1016/j.mib.2012.04.003

Vitetta, L., Briskey, D., Alford, H., Hall, S., and Coulson, S. (2014). Probiotics, prebiotics and the gastrointestinal tract in health and disease. Inflammopharmacology 22, 135-154. doi: 10.1007/s10787-014-0201-4

Vitetta, L., Hall, S., and Coulson, S. (2015). Metabolic interactions in the gastrointestinal tract (GIT): host, commensal, probiotics, and bacteriophage influences. Microorganisms 3, 913-932. doi: 10.3390/microorganisms3040913

Ythier, M., Resch, G., Waridel, P., Panchaud, A., Gfeller, A., Majcherczyk, P., et al. (2012). Proteomic and transcriptomic profiling of Staphylococcus aureus surface LPXTG-proteins: correlation with agr genotypes and adherence phenotypes. Mol. Cell. Proteomics MCP 11, 1123-1139. doi: 10.1074/mcp.M111.014191

Zarate, G. (2012). "Dairy propionibacteria: less conventional probiotics to improve the human and animal Health," in Probiotic in Animals, ed. E. Rigobelo (Rejika: InTech).

Conflict of Interest Statement: The authors declare that the research was conducted in the absence of any commercial or financial relationships that could be construed as a potential conflict of interest.

Copyright (c) 2017 do Carmo, Rabah, Huang, Gaucher, Deplanche, Dutertre, Jardin, Le Loir, Azevedo and Jan. This is an open-access article distributed under the terms of the Creative Commons Attribution License (CC BY). The use, distribution or reproduction in other forums is permitted, provided the original author(s) or licensor are credited and that the original publication in this journal is cited, in accordance with accepted academic practice. No use, distribution or reproduction is permitted which does not comply with these terms. 